\title{
MODERNISASI PENDIDIKAN ISLAM DI INDONESIA (Komparasi Pengalaman Organisasi Muhammadiyah dan Nahdlatul Ulama)
}

\author{
Saripuddin Daulay, Rasyid Anwar Dalimunthe \\ Kementerian Agama Kota Gunung Sitoli, Sekolah Tinggi Agama Islam Serdang Lubuk Pakam \\ E-mail: syarifudindaulay999@gmail.com, rad577rad@gmail.com
}

\begin{abstract}
How to Cite:
Daulay, S. Daimunthe, R.A. (2021). Modernisasi Pendidikan Islam di Indonesia (Komparasi Pengalaman Organisasi Muhammadiyah dan Nahdlatul Ulama). Fitrab: Journal of Islamic Education, 2(2), 125-140.
\end{abstract}

\begin{tabular}{l}
\hline ARTICLE HISTORY \\
Received : 19 December 2021 \\
Revised : 06 January 2022 \\
Accepted : 07 January 2022 \\
Published : 07 January 2022
\end{tabular}

\section{KEYWORDS:}

Modernisasi, Pendidikan Islam, Muhammadiyah, Nahdlatul Ulama

\begin{abstract}
This study aims to analyze the modernization of Islamic education in Indonesia from two organizations namely Muhammadiyah and Nahdlatul Ulama. The focus of the study is on aspects of modernization and the contribution of modernization to national education. This type of research is qualitative based on literature study. The results of the study explain that aspects of modernization, such as educational goals, Muhammadiyah directs it towards being firm in holding and practicing Islamic teachings sourced from the Qur'an and Hadith. Meanwhile, Nahdlatul Ulama aims to be moral-spiritual oriented which emphasizes the urgency of balance between religion and science. Aspects of the curriculum, Muhammadiyah and Nahdatul Ulama have something in common, namely incorporating science into their curriculum. There is almost no difference in the method aspect, although NU sometimes still maintains its classical methods such as Wetonan and Sorogan. Both aspects of human resource development demand to have the characteristics of organizational scholarship. Its contribution to the national education system, Muhammadiyah gave birth to schools with Islamic curricula which so far only taught science, the NU version gave birth to modern Islamic boarding schools, even tiered to the level of higher education.
\end{abstract}

\section{RIWAYAT ARTIKEL}

Diterima : 19 Desember 2021

Direvisi : 06 Januari 2022

Disetujui : 07 Januari 2022

Diterbitkan : 07 Januari 2022

\section{KATA KUNCI:}

Modernization, Education, Muhammadiyah, Nahdlatul Ulama

\section{ABSTRAK}

Penelitian ini bertujuan untuk menganalisis modernisasi pendidikan Islam di Indonesia dari dua organisasi yakni Muhammadiyah dan Nahdlatul Ulama. Fokus kajian pada aspek-aspek modernisasi dan kontribusi modernisasi terhadap pendidikan Nasional. Jenis penelitian ini kualitatif berbasis studi pustaka. Hasil penelitian menjelaskan bahwa aspek modernisasi, seperti tujuan pendidikan, Muhammadiyah mengarahkannya pada arah untuk keteguhan dalam memegang dan mengamalkan ajaran islam yang bersumber ai Al-Qur'an dan Hadis. Sedangkan Nahdlatul Ulama tujuanya berorientasi pada moralspiritual yang menegaskan urgensi keseimbangan antara ilmu agama dan sains. Aspek kurikulum, Muhammadiyah dan Nahdatul Ulama memiliki kesamaan yakni memasukkan ilmu sains kedalam kurikulumnya. Aspek metode hampir tidak ada perbedaan walaupun NU terkadang masih mempertahankan metode klasiknya seperti Wetonan dan Sorogan. Aspek pengembangan sumber daya manusia keduanya menuntut memiliki ciri khas keilmuan organisasi. Kontribusinya pada sistem pendidikan Nasional, Muhammadiyah melahirkan sekolah dengan kurikulum keislaman yang selama ini sekolah hanya mengajarkan sains semata, versi NU melahirkan pondok pesantren modern, bahkan berjenjang sampai tingkat tinggi. 
PENDAHULUAN

Modernisasi pendidikan Islam di Indonesia yang muncul sejak tahun 1900-an memang memberikan pengaruh yang besar bagi perkembangan pendidikan Islam di Indonesia. Kurun waktu tersebut mencatat banyak hal perubahan pada dunia pendidikan Islam di Indonesia, mulai dari institusi kelembagaan, sistem pendidikan, manajemen pengelolaan, sampai pada ragam kebijakan pemerintah yang juga turut megalami perubahan akibat arus modernisasi tersebut. Walaupun tidak selamanya perubahan itu bersifat positif akan tetapi perubahan itu telah menambah warna pendidikan Islam di Indonesia. Karena esensi dari modernisasi itu adalah perubahan maka wajar jika setiap perubahan diidentikkan dengan modernisasi, namun perubahan yang dimaksud disini ialah perubahan yang landasi tujuan untuk menjadi lebih baik.

Perubahan dan pengaruh yang ditimbulkan oleh kondisi modernisasi tidak akan berhenti sampai di satu titik saja, akan tetapi akan terus berlanjut seiring dengan perubahanperubahan yang dilakukan oleh pelaku modernisasi tersebut. Dalam dunia pendidikan semua orang yang terlibat dalam dunia pendidikan dapat menjadi pelaku atau penggagas modernisasi. Tapi dalam konteks tertentu modernisasi dapat lahir dari usaha, kewenangan, kebijakan atau pergerakan sebuah organisasi. Artinya dalam hal itu produk modernisasi bukan produk satu individu akan tetapi produk yang dihasilkan oleh banyak orang yang mengatasnamakan dirinya organisasi.

Negara Indonesia dikenal sebagai Negara yang memiliki oganisasi keislaman yang cukup banyak, dan hal itu merupakan suatu kewajaran dikarenakan mayoritas penduduk Indonesia ialah beragama Islam. Berdasarkan data dari Direktorat Jenderal Bimbingan Masyarakat Islam tahun 2013, bahwa jumlah Organisasi Kemasyarakatan Islam di Indonesia sebanyak 68 organisasi. Jumlah tersebut tersebar di seluruh wilayah Indonesia, ada yang berlokasi di Jakarta sebagai pusatnya ada juga yang di luar. Namun sepanjang sejarah dari 68 tersebut terdapat terdapat dua organisasi terbesar dan yang paling populer di Indonesia yakni organisasi Muhammadiyah dan Nahdlatul Ulama.

Muhammadiyah berdiri pada tahun 1912 di Yogyakarta sedangkan Nahdlatul Ulama berdiri tahun 1926 di Surabaya. Keduanya selama kurang lebih 10 dekade belakangan ini telah memiliki banyak pengikut, bahkan keberadaanya tersebar di seluruh wilayah Indonesia. Keberadaan dua organisasi tersebut cukup memberikan pengaruh yang signifikan, yang tidak hanya pada hal-hal keagaamaan semata, tetapi juga pada sisi sosial, ekonomi, dan termasuk juga pendidikan. Khusus dalam dunia pendidikan, lembaga pendidikan Islam yang berafiliasi kepada dua organisasi tersebut sangat banyak, bahkan hampir mendominasi. Kiprah kedua organisasi tersebut dalam dunia pendidikan memang tak diragukan lagi, bahkan 
jika mau diurut lebih jauh lagi, sejak zaman pra kemerdekaan kiprah mereka dalam dunia pendidikan sangatlah diperhitungkan.

Selain melahirkan banyak lembaga pendidikan, keberadaan dua organisasi tersebut juga melahirkan banyak ide-ide pembaharuan dalam dunia pendidikan Islam. Seperti Muhammadiyah misalnya yang dikenal dengan sekolah berbasis Islamnya, yang dahulu kerap dianggap sebagai sekolah yang hanya megajarkan pelajaran sains semata kini berubah menjadi sekolah yang juga mengajarkan pelajaran keislaman, bahka kental dengan suasana keislaman. Begitu juga Nahdlatul ulama yang sangat terkenal dengan lembaga pondok pesantrennya, dahulu kerap dianggap sebagai lembaga tradisional dan klasik, akan tetapi saat ini beberapa pesantren di bawah naungan NU bertransformasi menjadi pondok pesantren modern. Sebenarnya tidak hanya dari sisi kelembagaan saja pemikiran pembaharuan itu tampak, akan tetapi banyak hal lagi, seperti sumber daya manusia, sarana dan prasarana, status dan kedudukan dan sebagainya. Tentu kesemua itu memberikan warna baru bagi dunia pendidikan Islam di Indonesia.

Permasalahan yang kerap muncul tentang modernisasi ialah arah ataupun orientasi dari modernisasi yang kerap dianggap sebagai sikap menerima atau mengadopsi peroduk Barat, atau dianggap meninggalkan nilai-nilai tradisi keislaman. Dengan demikian tidak semua kalangan menerima ide-ide modernisasi, bahkan tak sedikit juga dari mereka yang secara terang- terangan menolak modernisasi versi barat. Untuk menilai arah dan orientasi dari sebuah modernisasi sebenarnya cukup melihat pelaku dari modernisasi tersebut. Muhammadiyah dan Nahdlatul Ulama tidak dikenal sebagai organisasi yang berafiliasi ke barat, melainkan organisasi yang resmi berafiliasi ke Indonesi, bahkan tumbuh dari kekhasan Indonesia.

Permasalahan lain yang kerap muncul tentang modernisasi ialah dominasi jati diri dari pendidikan Islam tersebut. Sebab selama ini banyak ditengarai bahwa pendidikan Islam yang ada saat ini kerap mengikut, meniru, atau meggunakan produk-produk pemikiran barat. Sehingga seolah-olah Islam tidak memiliki produk, tentu saja akibat itu pendidikan Islam kehilangan jati dirinya. Pendidikan Islam yang ada saat ini tidak tentu murni memang berdasarkan Al-Qur'an dan Hadis, tak dapat dielakkan kadang kala ditemukan beberapa kasus yang menunjukkan bahwa pendidikan Islam tidak sesuai dengan nilai-nilai keislaman yang sesungguhnya. Atas dasar itu lah pada periodisasi selanjutnya muncul gagasan modernisasi yang disebut dengan Islamisasi ilmu pengetahuan.

Lantas timbul pertanyaan, apakah konsep dan praktik yang dilakukan oleh Muhammadiyah dan Nahdlatul Ulama demikian? Tentu sebagai organisasi terbesar apapun konsep dan praktik yang dipilih oleh keduanya dalam hal perubahan praktik pendidika akan menjadi sorotan banyak pihak, bahkan menjadi satu dasar contoh untuk ditiru oleh 
banyak orang. Terlebih lagi para pengurus Muhammadiyah dan Nahdlatul Ulama berada dalam posisi pemerintahan, yang tentu dapat saja melahirkan kebijakan baru bagi dunia pendidikan Islam. Atas dasar itulah peneliti tertarik untuk mengangkat permasalahan tersebut menjadi penelitin yang dibingkai pada dua fokus pertanyaan yakni aspek-aspek modernisasi pendidikan dari kedua organisasi tersebut dan kontribusinya terhadap kebijakan pendidikan nasional.

$$
\text { Penelitian tentang modernisasi }
$$

pendidikan Islam memang kerap dilakukan seperti penelitian tentang modernisasi pendidikan perspektif pemikira Fazlur Rahman (Fazlurrahman, 2018), modernisasi pendidikan pesantren perspektif Azyumardi Azra (Heriyudanta, 2016), Modernisasi kurikulum pendidikan Islam di Indonesia (Sayyi, 2017), pendidikan Islam antara tradisi, dan modernisasi (Ichsan et al., 2020), gerakan pembaharuan pendidikan Islam Muhammadiyah (Yusra, 2018), respon Muhammadiyah tentang pendidikan Barat (Basinun, 2018), telaah sejarah sosial modernisasi pendidikan versi Muhammadiyah (Ilham \& Syamsuddin, 2021), modernisasi pendidikan Islam perspektif pengalaman Nahdatul Ulama (Muhammedi, 2016), namun dari kesemua penelitian tersebut masih terbatas pada pemikiran tokoh, atau pun organisasi Muhammadiyah dan Nahdlatul Ulama namun pembahasan yang disajikan secara parsial. Berbeda dengan penelitian ini yang menyajikan perbandingan dari dua organisasi, bahkan melihat signifikansinya terhadap sistem pendidikan Nasional.

Penelitian ini secara umum akan memaparkan tentang ciri khas dari pendidikan Islam baik di lembaga Muhammadiyah dan Nahdlatul Ulama, kemudian melihat latar perkembangan sosial yang menunjukkan gerakan pembaharuan atau modernisasi dalam bidang pendidikan Islam, lalu kemudian akhirnya melihat gerakan-gerakan tersebut dalam mempengaruhi kebijakan pendidikan nasional. Diharapkan penelitian ini berkotribusi bagi praktisi pendidikan tidak khusus bagi mereka yang berkecimpung pada kedua organiasi tersebut saja, terutama dalam menata arah dan orientasi dari pendidikan Islam di masa mendatang, sehingga anggapan ataupun persepsi bahwa pendidikan Islam modern cenderung mengarah ke Barat atau meninggalkan keislaman dapat di tepis.

\section{KAJIAN TEORI}

Kata Muhammadiyah diambil dari kosakata bahasa Arab, yaitu dari suku kata "mubammad" dengan arti menisbahkan sebagai umat dari Nabi Muhammad Saw. Adapun Muhammadiyah secara istilah merupakan gerakan organisasi Islam yang ada di Indonesia dalam rangka menjalankan Amar ma'ruf nabi mungkar, memiliki akidah yang kuat dengan AlQur'an dan as-sunnah sebagai sumber pokok ajarannya. Organisasi ini diprakarsai oleh K. H. Ahmad Dahlan, tepat pada tanggal 18 November 1912 di Yogyakarta. Tujuan utama 
didirikannya organisasi Muhammadiyah adalah untuk memurnikan kembali ajaran-ajaran Islam, atau menyelamatkan masyarakat muslim Indonesia dari berbagai penyimpanganpenyimpangan ajaran agama yang ada ketika itu, baik penyimpangan dalam beragama seperti dalam segi aspek beribadah atau aspek bernegara, karena kehidupan ketika itu banyak diwarnai oleh adanya fanatisme, bid'ah, konservatisme dan khurafat. Keadaan ini semakin memburuk dengan adanya misi kristenisasi yang dilaksanakan oleh bangsa kolonialisme, umat Muslim berada dalam Belenggu pemahaman dan praktek yang tidak selaras dengan ajaran agama Islam. (Delier Noer, 1980).

Lahirnya organisasi Muhammadiyah apabila dilihat dari segi pendidikan dilatarbelakangi oleh adanya dualisme sistem pendidikan, seperti adanya pendidikan kolonial Belanda dengan corak skuralistik dan diskriminatif. Skuralistik yang dimaksud disini adalah sistem yang memberlakukan pendidikan agama seakan dikesampingkan dalam kurikulum pendidikan, sedangkan pelajaran-pelajaran non agama mendapat posisi yang sakral dalam kurikulum. Adapun deskriminatif yang dilakukan oleh kolonial Belanda adalah adanya aturan yang memberlakukan bahwa tidak semua masyarakat diperbolehkan untuk mengenyam pendidikan di lembaga-lembaga pendidikan yang didirikan oleh kolonial, meskipun pada hakekatnya sistem pendidikan diterapkan oleh kolonial Belanda cukup bersifap modern. Latar belakang lainnya adalah adanya kesadaran masyarakat terhadap lembaga pendidikan tradisional yang dikelola oleh pribumi saat itu sudah mulai tidak sesuai dengan tuntutan zaman, sebab hanya mengajarkan pelajaran-pelajaran umum, dengan menggunakan metode-metode sorogan dan wetonan. pendidikan tradisional ketika itu juga masih memiliki administrasi yang belum memadai sebab dikelola secara individu oleh seorang guru atau kyai, tanpa adanya ketransparan, selain itu proses pembelajaran yang berlangsung masih bersifat pasif, peserta didik hanya menerima ppelajaran dari guru tanpa ada respon timbal balik dari siswa seperti adanya pertanyaan dan lain sebagainya. (Sutarto, 2020)

Berdasarkan hal di atas, maka K.H. Ahmad Dahlan melakukan modernisasi pendidikan dengan mendirikan lembaga pendidikan yang bercorak modern dengan berbagai pembaharuan di bawah naungan Muhammadiyah, seperti penggabungan antara sistem tradisional dengan sistem kolonial. Adapun tujuan dari penggabungan ini adalah untuk mengader peserta didik yang lebih unggul yaitu tidak hanya paham ilmu agama, namun juga memiliki intelektual tinggi dibidang lainnya. Secara sederhana modernisasi yang dilakukan oleh Muhammadiyah adalah untuk menghasilkan output pendidikan yang memiliki keimanan yang kokoh, mahir dalam keagamaan, serta memiliki skill dibidang lainnya seperti dalam kesehatan, sosial, politik, ekonomi dan lain sebagainya. (Delier Noer, 1980) 
Berbicara tentang Muhammadiyah tentu erat hubungaannya dengan tokoh yang telah memprakarsai organisasi tersebut yaitu oleh K.H. Ahmad Dahlan. K.H. Ahmad Dahlan sebagai tokoh masyarakat yang berkarismatik juga memiliki kontroversial dalam catatan sejarah hidupnya. Beliau merupakan tokoh yang lahir pada tanggal 1 Agustus tahun 1864 dan berpulang ke yang kuasa pada tanggal 22 Februari 1923. Orantua beliau adalah K.H. Abu Bakar yang memperistri putri dari H.Ibrahim (tokoh masyarakat yang berperan sebagai pejabat penghulu kesultanan di kota Yogyakarta pada masanya). Adapun nama nama kecil K.H Ahmad Dahlan adalah Muhammad Darwis, beliau dikenal sebagai sorang anak yang rajin dan ulet dalam belajar ilmu agama dan bahasa Arab. Sejarah perjalan beliau dalam dunia pendidikan dimulai dari beliau beranjak dewasa dan berangkat ke Makkah serta bermukim di sana selama 5 tahun untuk menuntut ilmu, guru beliau diantaranya adalah Sayyid Bakri Syatha (yang memberikan beliau nama baru yaitu Ahmad Dahlan), selain itu beliau juga belajar fikih dari K.H. Muhammad Shaleh, nahwu dengan K.H. Muhsin, ilmu falaq dengan K.H. raden dahlan, ilmu hadist dengan $\mathrm{KH}$. Mahfud dan Syekh Hayyat, serta ilmu qira'at yang ia peroleh dari Syekh Amin dan Syekh Bakri Satock, bahkan Ahmad Dahlan mempelajari ilmu pengobatan dan racun binatang dari Syekh Hasan. Juga diketahui bahwa Ahmad Dahlan sangat mengagumi pemikiran Ibnu Taimiyah, Muhammad Abduh, Rasyid Ridha dan
Jamaludin Al-Afghani (Arroisi, 2020). Hal ini terlihat dengan pemahaman dan pembaharuan Islamnya yang berfokus pada pemurnian (tauhid) dan tidak beriman secara taqlid. Dalam buku K.H. AR. Fahrudin (Ketua Muhammadiyah 1968) yang berjudul Menuju Muhammadiyah, menjelaskan mengenai hal-hal yang telah dilakukan KH. Ahmad Dahlan sepanjang kepemimpinannya, antara lain:

1. Meluruskan tauhid, Peng-Esaan terhadap Allah Swt. Meluruskan keberadaan Allah sebagai Sang khalik dan hubungan Allah dan makhluk-Nya tanpa perantara apapun

2. Meluruskan cara beribadah kepada Allah swt. Tanpa adanya gerakangerakan yang kurang tepat dalam shalat

3. Mengembangkan akhlakul karimah, etika sosial dan tata hubungan sosial sesuai tuntunan Islam. Jika diperhatikan secara garis besar maka bisa terlihat bahwa Ahmad Dahlan merupakan ciri Muslim fundamentalis yang mengembalikan semuanya kepada sumber utama Islam yakni Alquran dan Sunnah. Kemudian demikian beberapa pembaharuan yang dilakukan Ahmad Dahlan dalam hal; pembenaran arah kiblat di Masjid Agung Yogyakarta, pelurusan penetuan tanggal hari raya idul fitri yang ditentukan dengan hisab, penolakan terhadap bid'ah dan khurafat, dan perhatianya terhadap pendidikan 
dan gerakan kemasayarakatan (Deliai Noer, 1990).

Muhammadiyah sebagai organisasi dan gerakan sosial keagamaan yang telah didirikan oleh Kyai Ahmad Dahlan adalah gerakan yang bersifat tajdid atau pembaharuan-pembaharuan dalam pemikiran Islam yang disesuaikan dengan dengan kehidupan masyrakat, baik dalam kondisi sosial maupun budaya Indonesia pada umumnya. Muhammadiyah dalam perkembangannya mendapat respon yang baik dari masyarakat, sehingga bisa berkembang pesat dalam waktu singkat. Untuk mewujudkan berbagai gagasannya, K.H. Ahmad Dahlan mewajibkan pendidikan agama di sekolah Belanda yang bersifat skuler. Azyumardi Azra dalam bukunya mengistilahkan hal ini dengan Sekolah umum (Belanda) plus, selain itu beliau juga mendirikan lembaga pendidikan sekolah dengan sistem Pendidikan yaitu: mata pelajaran agama dan lainnya diajarkan tetap secara bersama-sama (Azumardi Azra, 2012). Dalam hal lain, Muhammadiyah juga bereksprimen dengan mendirikan madrasah yang bersifat modern. Hal ini terlihat dengan didirikannya Madrasah Mu'alimin dan Madrasah Mu'alimah. Kedua madrasah ini diselenggarakan dengan sistem dan kelembagaan seperti sekolah. Madrasah yang dikembangkan Muhammadiyah tidak memakai sistem dan kelembagaan yang bersifat tradisional, seperti surau, pesantren sebagai melainkan menggunakan sistem dan kelembagaan modern seperti yang dikembangkan oleh sekolah kolonial. Oleh sebab itu, usaha yang dikembangkan oleh Muhammadiyah dapat disimpiukan adalah dengan mengadakan pembahaiuan pcndidikan dengan jalan modernisasi dalam sistem pendidikan klasik menjadi sistem modern dan sesuai dengan tuntutan kehendak zaman.

Adapun NU merupakan sebuah organisasi Islam yang berdiri pada tanggal 31 Januari 1926 di Surabaya oleh K.H. Hasyim Asy'ari (Burhanuddin, 2012). K.H. Hasyim Asy'ari banyak mengembang ilmu Alquran dan dasar-dasar ilmu agama dari kedua orangtuanya. Dalam perjalan karir intelektualnya, beliau juga banyak menimba ilmu di pondok-pondok pesantren seperti halnya di ponpes Shona, Siwalan Buduran, Langitan, Tuban, Demangan, Bangkalan dan Sidoarjo. Setelah mendirikan pondok Pesantren Tebu Ireng, KH. Hasyim Asy'ari mewarnai lembaga pendidikannya dengan pandangan dan metodologi tradisional. Ia banyak mengadopsi pendidikan Islam klasik yang lebih mengedepankan aspek-aspek normatif, tradisi belajar-mengajar, dan etika dalam belajar yang dipandangnya telah mengantarkan umat Islam kepada zaman keeemasan. Dalam karyanya, Adab al-'Alim waAl-Mutta'allim, KH. Hasyim Asy'ari terlihat banyak dipengaruhi oleh tradisi pendidikan Islam klasik dan penulis-penulis klasik seperti Imam al-Ghazali dan Al-Zarnuji (Azra, 2013).

Ide modernisasi yang lahir dari NU pada hakikatnya adalah merupakan upaya sengaja yang dilakukan untuk menyelamatkan paham ahlu sunnah wal jama'ah, dari hal-hal yang 
menyimpang, khusunya dari sabotase yang dilakukan oleh para kaum pembaharu yang berasal dari golongan Wahabi, dan untuk memurnikan kembali ajaran agama sebagaimana yang sudah ada sejak zaman Nabi. Adapun rujukan kitab yang dipakai oleh NU untuk berpikir dan bertindak dalam kehidupan, selain Alquran sunah antara lain adalah kitab al-Qanun al-asasi li Jam eiyati Nahhdlatul al-Ulama (Prinsip Dasar NU), kitab Risalah Ahlusunnah wal Jama'ah, dan kitab Risalah Ahlusunnah wal Jama'ah. (Azra, 2012).

Pembentukan Nahdathul Ulama (Kebangkitan Ulama) sendiri setidaknya memiliki empat motif dalam pendiriannya. Motif yang pokok yang mendasari gerakan NU ini adalah motif keagamaan sebagai jihad fii sabilillah. Motif kedua adalah tanggung jawab dalam pengembangan pemikiran keagamaan yang ditandai dengan usaha pelestarian madzhab ahlussunnah wal jamaeah. Motif ketiga adalah dorongan untuk mengembangkan masyarakat melalui kegiatan pendidikan, sosial, dan ekonomi. Hal ini ditandai dengan terbentuknya Nahdathul Wathan, Tasywirul Afkar dan

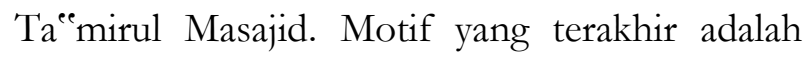
motif politik yang ditandai dengan semangat Nasionalisme serta obsesi mengenai hari depan negri merdeka bagi umat Islam. NU sebagai salah satu organisasi Islam terbesar di Indonesia memiliki peran yang signifikan dalam modernisasi pendidikan Islam. Pada awal berdirinya, Nahdlatul Ulama belum memiliki rumusan yang konkrit tentang pembaruan pendidikan. Akan tetapi pesantren-pesantren yang di asuh para kyai dengan sendirinya sudah merupakan aset besar di bidang pendidikan yang harus di urus Nahdlatul Ulama.

Pembaharuan-pembaharuan yang terjadinya pada dunia pendidikan NU seperti pada pesantren dan madrasah telah memunculkan atau mengkader peserta didik yang intelektual. K.H.A. Wahid Hasyim ketika menjabat sebagai Menteri Agama dan ketua Lembaga Pendidikan Ma'arif NU juga telah beruapaya untuk melakukan beberapa upaya pembaharuan atau modernisasi pada lembaga pendidikan pesantren dan madrasah melalui beberapa paradigma pengembangan, antara lain (Basori, 2006):

1. Pembaharuan paradigma dari teosentris ke anthroposentris dengan merekonstruksi tujuan pembelajaran di pesantren, yang semula santri diarahkan untuk mencetak ahli agama (ulama), dengan menyarankan agar tidak semua santri menjadi ulama, namun tetap memahami ajaran agama sebagaimana di pelajari di pesantren. Santri harus memperkuat diri dengan berbagai macam keahlian yang dalam dunia pendidikan sekarang dikenal dengan life skill education.

2. Perubahan paradigma dikotomik kepada non-dikotomik antara ilmu agama dan non-agama. Menurut Wahid Hasyim, bahwa materi yang diajarkan di pesantren dan madrasah haruslah merupakan ilmu-ilmu yang 
komprehensif yang tidak hanya mempelajari ilmu-ilmu agama yang bersumber dari kitab-kitab klasik saja.

3. Perubahan paradigma teoritik ke praktis. Dalam konsep ini Wahid Hasyim menekankan pentingnya pengamalan ilmu yang dipelajari di pesantren. Orientasi dari paradigma ini adalah terciptanya insan yang berakblakul karimah dan tujuan pendidikan bukan semata-mata transfer of knowledge namun juga transfer of values.

\section{METODE PENELITIAN}

Metode yang digunakan dalam penelitian ini adalah kualitatif menggunakan pendekatan kepustakaan (library research) yakni penyelidikan yang objek kajiannya memanfaatkan data pustaka berupa buku-buku sebagai sumber datanya. Penelitian ini dilaksanakan dengan membaca, menelaah, dan menganalisis berbagai literatur yang ada. (Moleong, 2007). Sumber data terdiri dari dua yakni sumber primer dan sumber sekunder. Sumber primer dalam penelitian ini adalah segala putusan ataupun aturan kebijakan yang dikeluarkan oleh muhammadiyah dan sekolah Islam terpadu. Sedangkan sumber sekunder berasal dari buku, artikel jurnal, hasil penelitian yang berkaitan dengan topik penelitian.

Data dikumpulkan menggunakan teknik dokumentasi, artinya mengumpulka data dari semua sumber bacaan yang menjadi sumber data penelitian. Kemudian diorganisasikan berdasarkan ketegori permasalahan, lalu kemudian dianalisis untuk diinterpretasikan menjadi temuan penelitian. Penarikan simpulan dapat dilakukan mana kala beberapa data yang dikumpulkan telah memenuhi keabsahan data. Untuk keabsahan data dilakukan dengan teknik content check point. Satu teknik yang digunakan untuk mengecek kebenaran tiap titik informasi yang akan dijadikan landasan dari penarikan simpulan, jika beberapa sumber data menunjukkan kesamaan informasi, barulah ditarik simpulan, jika berbeda maka akan terus dielaborasi, dan jika memang menunjukkan perbedaan akan disajikan sebagai temuan baru dalam penelitian. Alur metode penelitian sebagaimana berikut ini:

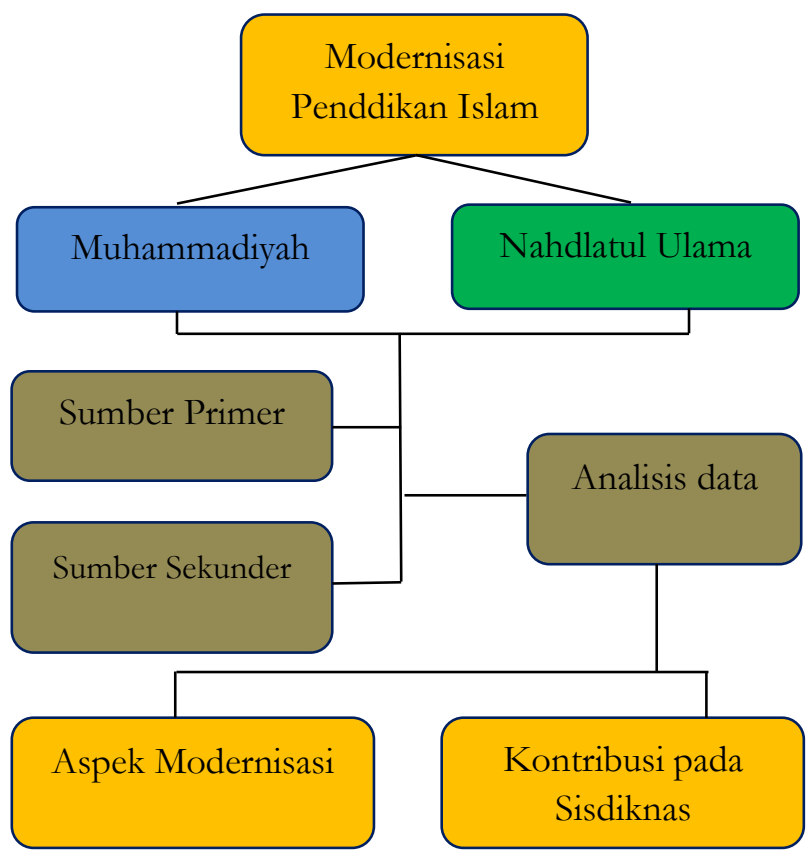

Bagan 1. Alur Penelitian

\section{HASIL DAN PEMBAHASAN PENELITIAN}

Sebagaimana yang telah disebutkan sebelumnya bahwa temuan penelitian akan diarahkan untuk menjawan dua fokus penelitian yakni aspek-aspek dari modernisasi pendidikan 
Islam, dan kontribusinya terhadap kebijakan pendidikan Nasional.

\section{Aspek Modernisasi Pendidikan (Tujuan,}

\section{Kurikulum, Metode dan SDM)}

Modernisasi dalam dunia pendidikan sebagaimana dijelaskan oleh Haidar Putra Daulay dipicu oleh beberapa alasan yang mendasar yaitu: 1) Pendidikan membutuhkan metode efektif yang dapat mengembalikan semangat berpikir peserta didik atau umat Islam, dalam rangka membangkitkan kejayaan Islam kembali, sebab jika terus monoton dengan metode tradisional, maka akan sulit untuk mengejar ketertinggalan umat Islam dari Barat.

2) Materi dalam Pendidikan Islam harus menyeimbangkan antara pelajran agama dan non agama, tidak lagi boleh terkotak-kotak dalam dikotomi pendidikan, sebab agama Islam tidak pernah membedakan kedua cabang ilmu tersebut, karena semua ilmu bersumber dari yang kuasa, 3) Manajemen Pendidikan yang lebih sistematis (Daulay, 2007).

Muhammadiyah dalam menanggapi modernisasi pada muktamar ke 42 pada tahun 1989 menetapkan tujuan dari pembaharuan atau tajdid adalah mengembalikan umat Islam kembali pada ajaran agama, menjadikan agama sebagai petunjuk dalam berbagai hal yang membawa rahmat bagi sekalian alam semesta, sehingga semua aspek pembaharuan dalam dunia pendidikan Islam harus tetap sejalan dengan ajaran agama, meskipun diadopsi dari berbagai sumber (Hidayat, 2016). Oleh sebab itu, khusus dalam tujuan pendidikan sebagaimana dirumuskan pada kongres Muhammadiyah seperempat abad tahun 1936 yang dilaksanakan di Jakarta menjelaskan bahwa agama Islam sebagai agama yang sempurna, serta iman, ilmu dan amal merupakan kesatuan yang tidak bisa dipisahkan, sebab iman ibarat akar dalam sebuah tumbuhan yang berfungsi menopang tegaknya ajaran agama Islam, sedangkan ilmu adalah batang pohon itu sendiri, yang akan memiliki berbagai cabang ilmu pengetahuan, baik ilmu pengetahuan agama seperti fikih atau non agama seperti fisika dan lain sebagainya dan yang terakhir adalah buah dari pohon tersebut diibaratkan adalah amal saleh yang akan membawa rahmat bagi sekalian alam. (Ja'far, 2010).

Oleh sebab, itu tujuan pendidikan dalam konsep pembaharuan pendidikan Islam versi Muhammadiyah ialah (1) memegang teguh serta mempertahankan, membela dan memperjuangkan ajaran Islam, (2) menjunjung tinggi ajaran agama dengan mengamalkan, serta melaksanakannya. (3) berpegang teguh pada ajaran Islam yang dibawa oleh Rasulullah Saw. sebagai agama yang sempurna untuk membentuk manusia yang sempurna.

Lainya halnya dengan Nahdlatul Ulama dalam memodernisasi tujuan pendidikan seperti dalam lingkup pesantren adalah dengan berorientasi pada moral-spiritual yang menegaskan urgensi keseimbangan antara ilmu agama dan non agama, sehingga mindset seluruh cifitas pendidikan, baik guru maupun peserta didik lebih realistis serta mampu menyeimbangkan antara kehidupan dunia 
dan akhirat, sebagaimana terdapat pada pesantren-pesantren yang diasuh oleh orangorang NU pada saat sekarang ini.

Selanjutnya dari aspek kurikulum, namun sebelumnya dapat dipahami bahwa kurikulum secara sederhana dapat diartikan seperangkat rencana dan pengaturan yang menjadi pedoman seluruh civitas pendidikan untuk mencapai tujuan pendidikan, dimana dalamnya berisi tujuan, isi, bahan pelajaran serta cara yang harus dilakukan dalam menggunakan atau melaksanakannya. Dalam aspek modernisasi kurikulum, Muhammadiyah menggunakan kurikulum modern dalam lembaganya yaitu memadukan pelajaran agama dan non agama seperti memasukkan pelajaran bahasa, akidah akhlak, fisika, biologi, geografi, tarikh islamiyah dan lain sebagainya.

Adapun kurikulum NU pada awalnya adalah berorientasi pada ilmu-ilmu keagamaan, sebab output yang diharapkan adalah munculnya generasi-generasi penerus para ulama. Akan tetapi seiring berjalannya waktu kurikulum NU berubah dengan menggabungkan ilmu-ilmu agama dengan ilmu pengetahun, serta berbagai keterampilan lainnya dan setelah pemerintah mensahkan SKB tiga Mentri, maka kurikulum lembaga pendidikan yang diasuh NU juga mengalami modernisasi kurikulum yang menjadi pelajaran $70 \%$ pelajaran agama dan $30 \%$ pelajaran lainnya dan yang terakhir adalah keluarnya kurikulum NU oleh pemerintah dengan mensesuaikannya dengan kebutuhan lembaga pendidikan yaitu 100\% keagamaan dan 100\% non keagamaan.

Nahdlatul Ulama melakukan modernisasi kurikulum pada lembaga pendidikannya dengan membuatnya lebih relevan serta sesuai dengan tuntutan sosio-historis (Sobari, 2010). Oleh sebab itu, hal ini menunjukkan bahwa NU mulai mengikuti system kemodernan untuk membekali peserta didiknya dalam menghadapi berbagai rintangan dimasa mendatang. Berbagai pembaharuan pendidikan juga terjadi pada aspekaspek pendidikan lainnya, seperti dari aspek metode, Muhammadiyah dan NU terus melakukan berbagai pembaharuan.

Selanjutnya modernisasi pada aspek metode yang lazim digunakan sebelumnya di berbagai lembaga pendidikan Islam adalah menggunakan sistem klasik, akan tetapi dengan maraknya ide pembaharuan, maka metode pendidikan mengalami modernisasi, seperti metode wetonan, bandongan, balaqah yang dilaksanakan dengan duduk bersila mengelilingi guru dalam rangka membaca kitab kuning mulai berubah menjadi metode yang menuntut peserta didik lebih aktif dalam pembelajran, begitu juga dengan metode sorogan yang dilakukan dengan membaca kitab masingmasing di depan guru, serta metode hafalan mulai di modernisasi dengan menggunakan berbagai metode yang lebih modern seperti eksprimen dan lain sebagainya.

Wacana modernisasi telah menyentuh semua aspek pendidikan, akan tetapi sebagaimana makna modernisasi salah satunya adalah memperbaharui yang lama menjadi sesuatu yang 
baru, maka dalam aspek metode ini, meskipun sudah menggunakan berbagai metode yang bersifat modern, akan tetapi bukan berarti langsung membuang metode yang lama, sebab ada juga yang menggabungkan antara metode klasik dengan metode modern dalam suatu lembaga pendidikan.

Sumber daya manusia menurut dalam undang-undang SISDIKNAS Nomor 20 tahun 2003 menjelaskan bahwa sumber daya manusia dibagi menjadi dua, yaitu sumber daya manusia dalam kategori tenaga pendidik dan tenaga kependidikan. Tenaga pendidik merupakan figur yang menjadi sosok proposional dalam merancang dan melaksanakan berbagai pembelajaran serta melakukan evaluasi, sedangkan tenaga kependidikan adalah personil yang melakukan bagian administrasi untuk menunjang terlaksananya proses pendidikan baik dalam pengelolaan, pengembangan dan pengawasan (Perawironegoro, 2018). Oleh sebab itu, khusus pendidik, maka Muhammadiyah memberikan beberapa indikator agar termasuk pendidik dalam ruang lingkup kemuhammadiyahan, antara lain yaitu Agama Islam, anggota simapatikan Muhammadiyah atau aisyiah, mempu memberikan uswatun khasanah, Ikhlas, tanggung jawab, Professional dalam bidang yang ditekuni

Adapun NU dari segi SDM juga terus melakukan modernisasi, sebagimana sebelumnya pendidik di lembaga pendidikan adalah pendidik yang di rekrut dari berbagai pesantren dengan notaben keagamaan, maka mulai mengalami perubahan dengan merekrut pendidik dari berbagai lulusan seperti lulusan universitas umum. Hal ini berkaitan dengan modernisasi kurikulum yang mulai memasukkan pelajaran-pelajran non agama yang menunutut adanya pendidik yang ahli dibidang tersebut. NU dalam rangka peningkatan SDM juga membentuk LAKPESDAM (Lembaga Kajian dan Pengembangan Sumber Daya Manusia) yaitu sebuah lembaga yang merupakan upaya implementasi gagasan kembali ke khittah sehingga meminimalisisr NU yang terlalu politisi sehingga agenda sosial keagamaan NU terabaikan.

NU juga mulai mengembangkan sayap ke Perth, Western Australia untuk memperkenalkan NU di luar negeri dengan tujuan untuk menungkatkan SDM NU dengan cita-cita menabur serpihan Islam yang sejuk, damai, dan toleran di negara yang penduduknya mayoritas non Muslim. Hal ini merupakan kebanggaan tersendiri karena yang menjadi pengusungnya adalah NU, sebagaimana Raihani sebagai Pembantu Dekan UIN Syarif Kasim, Pekanbaru, Rau, berinisiatif mendirikan Madrasah Darul Ma'arif di Perth, Western Australia mereka mendirikan Madrasah Darul Ma’arif di Perth, Western Australia.

Kelembagaan yang ada dalam lingkup Muhammadiyah dan $\mathrm{Nu}$ juga mengalami modernisasi seiring dengan perkembangan zaman. Hal ini dapat dilihat dari sejarang yang ada bahwa Muhammadiyah dalam memajukan dunia pendidikan terus mengalami perkembangan, lembaga yang dimiliki Muhammadiyah juga semakin lengkap, baik ditingkat dasar, MTs, MA bahkan sampai keperguruan tinggi dan sekarang lembaga pendidikan dalam perspektif 
Muhammadiyah dibagi menjadi dua yaitu: sekolah yang memiliki muatan kurikulum utamanya non agama, namun memiliki pelajaran agama yang bersifat wajib sebagai ciri khasnya dan yang kedua adalah sekolah agama, yaitu sekolah yang muatan kurikulumnya ilmu-ilmu keagamaan.

Modernisasi kelembagaan NU juga dapat dilihat dimana awalnya lembaga-lembaga NU berorientasi untuk mencetak generi penurus ulama di lembaga pendidikan pesantren, mulai memodernisasinya dengan mendirikan berbagai lembaga pendidikan formal, baik yang bersifat umum seperti SD, SMP, SMA/SMK serta lembaga pendidikan agama tentunya seperti MI, MTs, MA dan perguruan tinggi.

\section{Kontribusi Modernisasi Pendidikan Islam} Muhammadiyah dan Nahlatul Ulama Terhadap Pendidikan Nasional

Muhammadiyah merupakan salah satu organisasi terbesar di Indonesia yang telah berdiri dan terus berkembang sampai saat sekarang ini. Kontribusi dan pengaruah yang diberikan oleh Muhammadiyah juga tidak hanya dalam dunia sosial, namun juga dalam dunia pendidikan. Modernisasi pendidikan dalam rangka terus memperbaiki system pendidikan di Indonesia membawa umat Islam mencapai kembali kejayaannya telah berhasil diperkenalkan oleh Muhammadiyah kepada umat Islam di Indonesia dan mendapatkan posisi yang baik di hati umat. Sebagai organisasi yang membantu tugas pemerintah, Muhammadiyah juga telah banyak menuangkan ide-ide pembaharuannya dalam lembaga pendidikan yang ada di bawah nanungan Muhammadiah untuk menjadi tauladan bagi yang lain. Selain ide, Muhammadiyah juga mendirikan berbagai lembaga pendidikan formal untuk umat dengan gaya modern, sehingga umat memperoleh berbagai ilmu pengetahuan, baik ilmu agama maupun non agama, dalam rangka mencapai kehidupan yang bahagia dunia dan akhirat.

Hal ini senada dengan pernyataan Mitsuo Nakamura yang mengatakan bahwa Muhammadiyah telah berhasil memadukan sistem pendidikan klasik denga sekuler untuk dimodifikasi, sehingga memberikan kesadaran nasional bagi umat melalui ajaran agama Islam. Melalui lembaga yang telah didirikan oleh Muhammadiyah, umat Islam Indonesia juga lebih cepat mendapat, menerima dan menerapkan berbagai ide pembaharuan. Dengan demikian dapat disimpulkan bahwa Muhammadiyah telah berkontribusi besar dalam negara untuk meningkatkan pengetahuan modern umat di Indonesia (Siddik, 2007). Adapun pendirian lembaga pendidikan yang telah disumbangkan Muhammadiyah untuk Indonesia dapat dilihat pada table di bawah ini:

Tabel 1. Sebaran lembaga pendidikan Muhammadiyah di Indonesia

\begin{tabular}{|c|l|c|}
\hline No & Nama Lembaga & Jumlah \\
\hline 1 & SD/MI & 1094 \\
\hline 2 & SMP/MTs/MA & 1128 \\
\hline 3 & SMA & 558 \\
\hline 4 & SMK & 554 \\
\hline 5 & Pesantren & 326 \\
\hline 6 & Perguruan Tinggi & 162 \\
\hline
\end{tabular}


Berkaitan deng kontribusi dan pengaruh, maka NU juga tidak kalah dalam memberikan pendidikan yang terbaik untuk masyarakat Indonesia. Hal ini dapat dilihat dari sistem pendidikan yang dirancang dan dikembangkan oleh NU secara mandiri, seperti dalam segi pengelolaan pendidikan mandiri yang telah mandarah daging dan menjadi salah satu prinsip dalam diri masyarakat dalam membangun pendidikan nasional yang lebih maju. Selai itu, NU juga telah memberikan kesadaran umat akan pentingnya sebuah organisasi dalam rangka melakukan pembaharuan dan pergerakan (Muzadi, 2007).

Contoh kongkrit kontribusinya masa awal NU salah satunya adalah pendirian UNUSU (Universitas Nahdlatul Ulama Sumatera Utara) di Padang Sidimpuan yang merupakan cikal bakal dari Institut Agama Islam Negeri Sumatera Utara (IAIN-SU) atau UINSU (Universitas Islam Negeri Sumatera Utara) saat sekarang ini, disebabkan keinginan pemerintah atau mentri agama untuk mengalihkannya menjadi dibawah naungan pemerintah. Begitu juga dengan beberapa Lembaga yaitu Perguruan Tinggi Agama Islam Tapanuli Selatan pada tahun 1960, PERTINU tahun 1962, UNU SU, Fakultas Tarbiyah tahun 1963, Fakultas Ushuluddin tahun 1965, Fakultas Dakwah tahun 1970, Fakultas Pengetahuan Masyarakat tahun 1978, UNUSU/Yayasan KH. Zainul Arifin: Fakultas Syariah, 1967.

Adapun sekarang ini NU yang telah aktif berkontribusi mencerdaskan anak bangsa Indonesia hal itu terbukti dari semakin banyaknya sebaran lembaga pendidikan yang berafiliasi ke Nahdlatul
Ulama, adapun data sebaran yang dimaksud sebagai berikut (Rahim, 2013):

Tabel 2. Sebaran Lembagaa Pendidikan Nahdlatul Ulama di Indonesia

\begin{tabular}{|l|l|c|}
\hline No & Nama Lembaga & Jumlah \\
\hline 1 & MI & 7452 \\
\hline 2 & MTs & 2991 \\
\hline 3 & MA & 1002 \\
\hline 4 & PT & 81 \\
\hline 5 & SD & 80 \\
\hline 6 & SMP & 718 \\
\hline 7 & SMA & 137 \\
\hline 8 & SMK & memiliki \\
\hline
\end{tabular}
kontribusi dan pengaruh yang sangat besar dalam dinamika perkembangan pendidikan Islam di Indonesia, dengan berbagai modernisasi modernisasi yang telah dilakukan. kontribusi yang paling besar salah satunya adalah dengan banyaknya lembaga-lembaga pendidikan yang berdiri di atas naungan NU melalui LP. Ma'arif, baik dari jenjang tingkat dasar, tingkat menengah, tingkat atas, sampai ke jenjang perguruan tinggi dengan sistem yang relevan dengan perkembangan zaman.

\section{SIMPULAN}

Berdasarkan uraian di atas maka dapat ditarik simpulan yakni beberapa aspek modernisasi, seperti modernisasi pada aspek tujuan pendidikan, Muhammadiyah mengarahkannya pada memegang teguh serta mempertahankan, membela dan memperjuangkan ajaran Islam, menjunjung tinggi ajaran agama dengan mengamalkan, serta 
melaksanakannya, dan berpegang teguh pada ajaran Islam yang dibawa oleh Rasulullah Saw. sebagai agama yang sempurna untuk membentuk manusia yang sempurna. Sedangkan Nahdlatul Ulama tujuan pendidikan di modernisasi yang berorientasi pada moral-spiritual yang menegaskan urgensi keseimbangan antara ilmu agama dan non agama, sehingga mindset seluruh civitas pendidikan, baik guru maupun peserta didik lebih realistis serta mampu menyeimbangkan antara kehidupan dunia dan akhirat. Pada aspek kurikulum sebenarnya antara Muhammadiyah dan NU memiliki kesamaan yakni memasukkan ilmu-ilmu sains kedalam kurikulumnya yang sebelumnya tidak dimasukkan. Begitu juga dengan metode hampir tidak ada perbedaan walaupun memang NU kerap masih mempertahankan beberapa metode klasiknya seperti Wetonan, Sorogan, dan Bandongan. Dari aspek pengembangan SDM keduanya menuntut agar SDM memiliki ciri khas keilmuan organisasi seperti Muhammadiyah dengan Ikatan Guru Muhammadiyah, dan NU dengan persatuan guru Nahdatul Ulama (Pergunu). Simpulan kedua terkait dengan kontribusinya pada sistem pendidikan Nasional, Versi Muhammadiyah melahirkan sekolah yang akhirnya mengajarkan kurikulum keislaman dari yang selama ini hanya mengajarkan kurikulum sains semata, sedangkan dalam versi NU melahirkan pondok pesatren modern, bahkan berjenjang sampai pada tingkat pendidikan tinggi.

\section{DAFTAR PUSTAKA}

Arroisi, J. (2020). Pembaharuan Pemikiran Islam Model Muhammadiyah Dan Nahdlatul Ulama, dalam Jurnal Islam. Nusantara, 4(2),
175.

Azra, Azumardi. (2012). Pendidikan Islam: Tradisi dan Moderniasai di Tengah Melinim III. UIN Press.

Azra, Azyumardi. (2013). Jaringan Ulama Timur Tengah \& Kepulauan Nusantara Abad XVII dan XVIII. Kencana.

Basinun, B. (2018). Modernisasi Pendidikan Islam di Indonesia: Respon Muhammadiyah Terhadap Model Pendidikan Barat. At-Ta'lim: Media Informasi Pendidikan Islam, 16(2), 255-275. http://dx.doi.org/10.29300/attalim.v16i2.8 37

Basori, R. (2006). The Founding Father Pesantren Modern Indonesia, Jejak Langkah K.H.A. Wabid Hasyim. Inceis.

Burhanuddin, J. (2012). Ulama dan Kekuasaan; Pergumulan Elit Muslim Dalam Sejarah Indonesia. Mizan.

Daulay, H. P. (2007). Sejarah Pertumbuban dan Pembaruan Pendidikan Islam di Indonesia. Kencana.

Fazlurrahman, M. (2018). Modernisasi Pendidikan Islam: Gagasan Alternatif Fazlur Rahman. Ta'lim: Jurnal Studi Pendidikan Islam, 1(1 SE-Articles). http://ejurnal.unisda.ac.id/index.php/talim/article /view/634

Heriyudanta, M. (2016). Modernisasi Pendidikan Pesantren Perspektif Azyumardi Azra. Mudarrisa: Jurnal Kajian Pendidikan Islam, 8(1), $\quad$ 145-172. https://doi.org/10.18326/mdr.v8i1.145172

Hidayat, S. (2016). Studi Kemubammadiyahan Kajian Historis, Ideologi dan Organisasi, Anggaran Dasar Mubammadiyah Bab III Pasal 6. LPIK.

Ichsan, A. S., Sembiring, I. D., \& Luthfiah, N. (2020). Pendidikan Islam Menghadapi Tradisi, Transisi, dan Modernisasi. Fitrab: Journal of Islamic Education, 1(1), 107-123. 
Ilham, I., \& Syamsuddin, I. P. (2021). Pendidikan Islam: Telaah Sejarah Sosial Keagamaan dan Modernisasi Pendidikan Muhammadiyah. Tajdid: Jurnal Pemikiran Keislaman dan Kemanusiaan, 5(2), 199-216. https://doi.org/10.52266/tadjid.v5i2.704

Ja'far, D. S. dan. (2010). Jejak Langkah Intelektual Islam: Epistemologi, Tokoh dan Karya. IAIN Press.

Moleong. (2007). Metodologi Penelitian Kualititatif. Remaja Rosda Karya.

Muhammedi, M. (2016). Modernisasi Pendidikan Islam Indonesia Pengalaman Nahdlatul UlamA. Jurnal Tarbiyah, 23(2), 211-233. http://dx.doi.org/10.30829/tar.v23i2.113

Muzadi, A. M. (2007). NU Dalam Perspektif Sejarah dan Ajaran. Khalista.

Noer, Deliai. (1990). Gerakan Modern Islam di Indonesi1990-1924. LP3S.

Noer, Delier. (1980). Gerakan Modern Islam di Indonesia 1900-1942. LP3ES.

Perawironegoro, D. (2018). Pengembangan Sumber Daya Manusia di Lembaga Pendidikan Islam. Tajdidukasi, 8(1), 2.

Rahim, A. (2013). Nahdatul Ulama (Peranan dan Sistem Pendidikannya). Jurnal Al Hikmah, 14(2), 182.

Sayyi, A. (2017). Modernisasi Kurikulum Pendidikan Islam dalam Perspektif Azyumardi Azra. Tadris: Jurnal Pendidikan Islam, 12(1), 20-39. https://doi.org/10.19105/tjpi.v12i1.1285

Siddik, D. (2007). Pendidikan Muhammadiyah Perspektif Ilmu Pendidikan. Ciptapustaka.

Sobari, M. (2010). NU dan Keindonesiaan. PT Gramedia Pustaka Utama.

Sutarto. (2020). Kiprah Muhammadiyah Dalam Pembaharuan Pendidikan dan Sosial Keagamaan di Nusantara: Kajian Terhadap Pemikiran KH. Ahmad Dahlan. Jurnal Pendidikan Islam, 5(1), 2-3.
Yusra, N. (2018). Muhammadiyah: Gerakan Pembaharuan Pendidikan Islam. Potensia: Jurnal Kependidikan Islam, 4(1), 103-125. http://dx.doi.org/10.24014/potensia.v4i1. 5269 